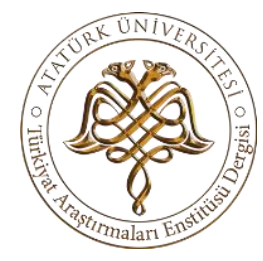

\title{
TÜRKÇE ÖĞRETIMINDE MIZAH: DERS KITAPLARI ÖRNEĞI
} HUMOR IN TURKISH TEACHING: SAMPLE OF TURKISH COURSE BOOKS

\section{DILEK ÜNVEREN}

Dr. Öğr. Üyesi, Süleyman Demirel Üniversitesi, Eğitim Fakültesi, Türkçe ve Sosyal Bilgiler Eğitimi Bölümü Assist. Prof. Dr., Süleyman Demirel University, Fac. of Education, Dep. of Turkish and Social Studies Education dilekkapanadze@sdu.edu.tr

(iD) https://orcid.org/0000-0003-3415-9274

\section{Atıf / Citation}

Ünveren, D. 2020. “Türkçe Öğretiminde Mizah: Ders Kitapları Örneği”. Türkiyat Araştırmaları Enstitüsü Dergisi - Journal of Turkish Researches Institute. 67, (Ocak-January 2020). 715-735

\section{Makale Bilgisi / Article Information}

Makale Türü-Article Types : Araştırma Makalesi-Research Article

Gelis Tarihi-Received Date : 30.08 .2019

Kabul Tarihi-Accepted Date : 11.12 .2019

Yayn Tarihi- Date Published : 31.01 .2020

dof : http://dx.doi.org/10.14222/Turkiyat4289

Intihal / Plagiarism

This article was checked by $\boldsymbol{V}$ iThenticate programında bu makale taranmıştur.

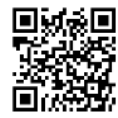

Türkiyat Araştırmaları Enstitüsü Dergisi - Journal of Turkish Researches Institute TAED-67, Ocak - January2020 Erzurum. ISSN-1300-9052 www.turkiyatjournal.com $\underline{\text { http://dergipark.gov.tr/ataunitaed }}$ 



\section{Atatürk Üniversitesi • Atatürk University \\ Türkiyat Araştırmaları Enstitüsü Dergisi • Journal of Turkish Researches Institute \\ TAED-67, 2020. 715-735}

\section{TÜRKÇE ÖĞRETIMINDE MIZAH: DERS KITAPLARI ÖRNEĞI* HUMOR IN TURKISH TEACHING: SAMPLE OF TURKISH COURSE BOOKS}

\section{DİLEK ÜNVEREN}

\begin{abstract}
$\ddot{O} \mathbf{z}$
$\mathrm{Bu}$ çalışmanın amacı gelişim psikolojisinin önemli bir alanı olan mizah gelişiminin ne olduğunu, Türkçe öğretiminde kullanılan ders kitaplarının bu gelişim alanını ne yönde ve ne kadar desteklediğini ortaya koymaktır. Nitel bir yaklaşımla ele alınan ve betimleyici durum çalışması deseninde oluşturulan bu çalışmada veriler doküman incelemesi yöntemi ile toplanmış, Millî Eğitim Bakanlığı 5, 6, 7 ve 8. Sinıf Türkçe ders kitapları içerdikleri mizahi ögeler bakımından analiz edilmiş ve karşılaştırılmıştır. Elde edilen veriler betimsel analiz yoluyla çözümlenmiş ve dikkatlere sunulmuştur. Sonuç olarak, Türkçe ders kitaplarında (5-8) mizah ögeleri ihtiva eden metinler bütün ünitelerde değil, daha çok 'Çocuk Dünyası', 'Millî Kültürümüz', 'Birey ve Toplum' gibi temalarda yoğunlaşmıştır. Mizahi yapıları barındırması yönünden nicelik olarak dağılım her düzeydeki ders kitabında farklıdır. Kitaplarda yazılı ve görsel mizah ögeleri bir arada kullanılmış olsa dahi yazılı mizah ögeleri daha ağır basmaktadır. Görsel mizah ögelerinden en fazla malzeme karikatür ve resimler şeklinde görülmektedir. Yazılı mizah ögeleri anlatmaya dayalı, söylemelik, konuşmalık türler içerisinde yer almakta; atasözü, deyim, kinayeli ifadeler, zitlıklar, abartmalar gibi ögelerle de kendini göstermektedir. Mizah unsurları geleneksel Türk tiyatrosu içerinde Karagöz'de, diğer türler içerisinde ise fikra, öykü gibi yapılarda bulunmaktadır.
\end{abstract}

Anahtar Kelimeler: Türkçe Öğretimi, mizah, ders kitaplan
The aim of this study is to reveal the development of humor in students which is an important area of developmental psychology, and how and in what direction the textbooks used in Turkish teaching support this development area. In this qualitative research, which was designed as a descriptive case study, the data were collected by document analysis method, and 5, 6,7 and 8th grade Turkish textbooks of the Ministry of National Education were analyzed and compared in terms of their humor elements. Data were analysed by descriptive analysis method. As a result, texts containing humor elements in Turkish textbooks (58) are not concentrated in all units but rather in themes such as 'Children's World', 'National Culture', 'Individual and Society'. The distribution of quantity in terms of including humorous structures is different in textbooks at all levels. Even though written and visual humor elements were used in the books, written humor elements predominate. Most of the visual humor elements were presented as cartoons and pictures. Written elements of humor were manifested by such elements as proverbs, idioms, allusive expressions, contrasts, exaggerations. Humor elements were found in traditional Turkish theater in Karagöz, and in other genres, they were found in structures such as jokes and stories.

Key Words: Teaching Turkish, humor, textbooks

\footnotetext{
${ }^{*}$ Bu araştırma, 03-05 Ekim 2019 tarihinde İzmir'de düzenlenen 12. Uluslararası Türkçenin Eğitimi-Öğretimi Kurultayında sözlü bildiri olarak sunulan çalışmanın genişletilerek makale hâline dönüştürülmesiyle oluşturulmuştur.
} 


\section{Structured Abstract}

The aim of this study is to reveal the development of humor in students which is an important area of developmental psychology, and how and in what direction the textbooks used in Turkish teaching support this development area. In this qualitative research, which was designed as a descriptive case study, the data were collected by document analysis method, and 5, 6, 7 and 8th grade Turkish textbooks of the Ministry of National Education were examined and compared in terms of their humor elements. Data were analysed by descriptive analysis method.

We reached at following results at the end of the research:

The fifth grade Turkish textbook consists of 8 themes. In all the themes, humorous elements are included and humor structures are used both to entertain and to provide with positive behavior.

The sixth grade Turkish textbook consists of 8 themes. It was observed that humorous structures were not included only in the texts in the theme of 'National Struggle and Atatürk'. Texts were found to be predominant in humorous story genres.

Humor includes sharing first of all. Moreover, sharing has an undeniable place as a behavior in overcoming the feeling of insecurity. Sharing is important in strengthening the feelings of togetherness, sincerity, and friendship, and humor can serve as a bridge in understanding different cultures (Topçuoğlu, 2007). Grade 7, which is an important stage of social development, also refers to a period of development in which the individual's sense of belonging to a group is strengthened. In this sense, it can be stated that humor structures were found enough in the 7th grade textbook and humor elements were used successfully. The elements of humor were not included in the theme of 'National Struggle and Atatürk'.

Humor is recommended because it plays a powerful role in facilitating children's intellectual, social, emotional, mental, and personality development (McGhee, 2002), and studies on it are increasingly underway. Having a good sense of humor in the real sense will bring along many useful situations such as coping with negative situations and facilitating social cohesion. However, the textbook prepared for the 8th grades, which is at the beginning of the first years of youth regarding developmental stages, lags behind the other textbooks in containing humor structures and in the development of the above-mentioned skills.

Therefore, the findings can be summarized as follows:

1. Texts containing humor elements in Turkish textbooks (5-8) can not be found in all the themes and are mostly focused on the themes of 'Children's World', 'Our National Culture', 'Individual and Society.

2. The distribution of quantity in terms of containing humorous structures is different in the textbooks at all levels; in 13 texts of 5th grade textbook; in 14 texts of 6th and 7th grade textbooks, humorous elements were found, while in the 8th grade textbook only 5 texts were found to include humorous elements.

3. Even though written and visual humor elements were used in the books, written humor elements were found to predominate.

4. Most of the visual humor elements are in the form of cartoons and pictures.

5. Written elements of humor were shown in proverbs, idioms, allusive expressions, contrasts, exaggerations and in such elements.

6. Humor elements were found in traditional Turkish theater in Karagöz, and in other genres there are jokes and stories. Many genres of humorous traditional Turkish genre could not be observed; genres such as puppets have been found in the books as texts explaining the characteristics of the genre, not in the form of plays where humor characteristics are reflected.

7. The texts in which the humorous structures exist are in the direction of positive humor, which is self-enhancing and participatory.

8. Only Nasrettin Hodja jokes were included to represent jokes, other types of jokes were not observed. 
As a conclusion, texts containing humor elements in Turkish textbooks (5-8) are not concentrated in all units but rather focused on the themes of 'Children's World', 'National Culture', 'Individual and Society'. The distribution of quantity in terms of including humorous structures is different in textbooks at all levels. Even though written and visual humor elements were used in the books, written humor elements predominate. Most of the visual humor elements were presented as cartoons and pictures. Written elements of humor were shown in proverbs, idioms, allusive expressions, contrasts, exaggerations and in such elements.

Humor elements were found in traditional Turkish theater in Karagöz, and in other genres, they were found in structures such as jokes and stories. So, Turkish textbooks need to be enriched by including humorous elements of traditional Turkish genres. Moreover, 8th grade textbook need to be supported in terms of texts that include humor and structures that creates humor.

\section{Giriş}

Gülmece sözcüğüyle birlikte kullanılan mizah sözcüğü Türkçe Sözlük’te (2011), "eğlendirmek, güldürmek ve birine bir davranışı incitmeden takılmak amacını güden ince alay, humor" şeklinde tanımlanmıştır. Bununla beraber olayların gülünç yönlerini görme yeteneği, nüktedanlık, şakacılık, gülünçlük, güldürü şeklinde de tanımlanan mizah üzerine gerçekleştirilen psikolojik çalışmaların çoğunda, mizah duygusunun ruhsal sağlık ve iyilik durumuna olumlu yönde katkıda bulunan, olumlu ve istendik bir kişilik özelliği olduğu vurgulanmaktadır. Bu yönde yapılan araştırma bulgularına göre yüksek mizah duygusu gelişmiş insanlar, iyimser, kendini kabul noktasında olumlu ve tutarlı, özgüven ve özerlik algısı yüksek kişiler olarak tespit edilmiştir (Teker ve diğerleri, 2018).

Mizah evrensel bir kavramdır ve güldürmesi, eğlendirmesi gibi yönleriyle de büyük, geniş kitlelere ulaşma özelliği bulunmaktadır. İşte bu nedenle eğitsel boyutu da olan mizahın kullanım alanı da geniştir.

\section{Mizah Kuramları}

Bergson, bir topluluk hâlinde bulunan insanların tamamının, duyarlılıklarını bir tarafa bırakmak kaydıyla, sadece zekâlarını ortaya koyarak ve dikkatlerini herhangi birine yönelttikleri takdirde komiğin meydana geleceğini ifade eder (Bergson, 2011). Zira duyarlı bir kişi komik unsurunun hâkim olduğu bir durumla karşılaştığında duygularının etkisiyle hareket edeceğinden gülme eylemini gerçekleştiremez. Yine Bergson'a göre (2011) insana ait ve ona özgü olmayan herhangi bir şey için komik unsuru yoktur ve komiğin kaynaklarını ifade ederken söz komiği, devinimlerin komiği, durum komiği, biçim komiği ve karakter komiği başlıklarına vurgu yapar.

John Morreall ise komiğin bir sonucu olan 'gülme' den hareketle komiğin kaynağını belirlemeye çalışır. Gülme eylemini; 'üstünlük, uyumsuzluk, rahatlama ve yeni bir kuram olarak ileri sürdüğü, güzel bir psikolojik değişimden kaynaklanan gülme’ şeklinde dört temel kuramsal yapıya dayandırır. Kişinin karşısındakine karşı kurduğu üstünlük ve bu durumun sonucu olarak ortaya çıkan gülme eylemi, mizah olgusuna farklı bir bakış açısının getirilmesine ortam hazırlamıştır. Üstünlük kuramı olarak ifade edilen bu yaklaşıma göre kendisine karşı herhangi bir insani durum ya da özellik konusunda üstünlük kurulan kişiye gülünür (Morreall, 1997). Eker bu durumu şöyle ifade etmektedir: 
Rakibi saf dışı bırakmaktan duyulan keyif, bir başkasını dezavantajlı duruma getirmenin verdiği haz, öteki konumundaki kişinin düştüğ̈̈ kötü durumdan duyulan mutluluk, başkalarınin talihsizliklerinden ve acılarından alınan zevk, bedensel çirkinlik veya bozuklukların kendi bedeninde olmamasindan duyulan memnuniyet ile manttksı hareket ve eylemlere gülme yer almaktadır (2009).

Temelinde, gerilimi azaltmak ve rahatlamayı sağlamak olan rahatlama kurami; aynı zamanda psikoanalitik kuram olarak da kaynaklarda yer almaktadır (Şahin, 2018). Bu kurama göre gülme, baskı nedeniyle biriken sinirsel enerjinin ani boşalımı şeklinde tanımlanır (Şahin, 2018). Uyumsuzluk kuramı ise; gülme eyleminin düşünce merkezli olan yönünü ifade etmektedir. Nitekim bu teoriye göre gülme eylemi; mantık dışı, hiç umulmadık bir anda gerçekleşen duruma karşı verilen zihinsel tepkiyi ifade etmektedir. Bir diğer ifadeyle umulmadık bir olay gerçekleştiğinde meydana gelen gülme eylemidir.

\section{Mizah Tarzları}

Mizahın dinamizmini ve kullanım şeklini anlayabilmek için mizah çok boyutlu bir şekilde kavramsallaştırılmıştır. İște bu nedenle mizah tarzları öne sürülmüştür. Bu anlamda dört mizah tarzından söz edilebilir. Bunlar:

1.Kendini Geliştirici Mizah

2. Katılımc1 Mizah

3. Saldırgan Mizah

4. Kendini Yıkıcı Mizah (Şahin, 2018).

Daha benmerkezci bir mizah tarzı olan kendini geliştirici mizahı kullanan insanlar, hayata dair mizahi bir bakış açısına sahipken katılımcı mizah tarzına sahip bireyler ise genel itibariyle sosyal etkileşimi geliştirmeyi amaçlarlar. Karşı tarafı tehdit içerikli alay veya kırıcı şakalarla kendi çıkarları için kullanma eğilimine sahip bireyleri ifade eden saldırgan mizah eğilimi sağlıksız bir mizah tarzı olarak görülmektedir. Kendini aşağılayıcı mizah tarzı olarak da bilinen kendini yıkıcı mizah da tıpkı saldırgan mizah gibi sağlıksız bir başka mizah türüdür.

\section{Mizah, Bir Türe Özgülenebilir mi?}

Birtakım araştırmacılar tarafindan bağımsız, müstakil bir sanat dalı olarak görülmeyen ve resimde mizah, tiyatroda mizah gibi adlandırmalarla başka sanatlar içinde ele alınan mizah kavramı, yazın (edebiyat) içinde değerlendirilirken tek bir türe özgülenebilir bir anlatım tarzı mıdır, sorusuyla anlaşılmaya çalışılır (Usta, 2009). Bu anlamda mizah bağımsız bir tür olmaktan ziyade yazınsal türler içerisinde kendine yer bulan bir anlatım tarzı olarak ele alınmıştır. Bununla birlikte, mizah sadece yazınsal türlerin bir anlatım tarzı değildir, onun aynı zamanda karikatür, resim, müzik gibi sanatların yanında göstermeye bağlı metinlerin de önemli bir anlatım tarzı olduğu da unutulmamalıdır. Mizahi yapıların roman, öykü, şiir gibi edebi türlerin yanında; modern ve geleneksel tiyatro türlerinde, resim, karikatür, müzikte de olabileceği gözden kaçırılmamalıdır. Genel itibariyle mizahi türler ise şunlardır: komedi/komedya, mizahi öyküler, şiirler, fikralar, karikatür, ortaoyunu, kukla, meddah, Karagöz, köy seyirlik oyunları, şaka, alay, latife, ironi, hiciv, resim, şarkılar vb. 


\section{Ulusal Mizah, Evrensel Mizah}

Şüphesiz mizah; uluslara, toplumsal sınıflara hatta aynı topluluk içindeki çeşitli gruplara göre farklılaşır. Öyle ki mizah, içinde geliştiği toplumun sosyo-ekonomik şartlarına, kültürel yapı ve düzeyine, tarihine, gelenek ve göreneklerine bağlı olarak farklılıklar arz eder (Nesin, 2011). Her toplumun dünyayı adlandırma formunun değişiklik göstermesi ve özellikle dille yaratılan bir unsur olması nedeniyle mizahın topluluklarda, gruplarda farklı olması doğal bir sonuçtur. Nitekim mizahi fikralar bu anlamda toplumların bir olaya, duruma gülme eyleminde farklılaştı̆̆ını gösteren en önemli mizah unsurlarıdır. Ancak bir sınıfa, topluma ait mizah yapılarında farklı toplum unsurlarına rastlanabilir ve bunlar mizah ögesi olarak kullanılabilir. Bu anlamda mizahın bir mizaç olduğu ve bu prensip üzerine meydana geldiği unutulmamalidır.

\section{Çocuklarda Mizah Gelişimi}

Yetişkinlerle çocukların belli dönemlerde birbirlerinden farklı şeylere güldükleri bilinen bir durumdur. Morreall (1997) çocukların yetişkinlerin şakalarını anlamakta güçlük çekmelerinin, kavrayışlarındaki birtakım kalıpların yeterince olgunlaşmaması ile ilgili olduğunu söyler. Ayrıca çocukların ortaya koydukları davranışların kendileri tarafindan komik olsun diye yapılmamasına rağmen yetişkinlerin bunu komik bulmasının da farklı bakış açılarının dolayısıyla farklı bir kavrayışın etkisi olduğunu ifade eder. Farklı kültür yapılarından gelen yetişkinlerin mizah anlayışlarındaki farklılıkların da bundan kaynaklandığını belirtir.

Literatürde mizah gelişimiyle ilgili olarak farklı birçok bakış açısı ortaya konmuş olsa da mizah gelişimiyle ilgili iki temel görüş hâkimdir. Bunlar: Mizahı Freud'un psikoanalitik görüşlerinden beslenerek ortaya koyan Wolfstein ve bilişsel gelişimle ilişkilendirmek kaydıyla görüşlerini ortaya koyan McGhee'nin kuramıdır. Bunlardan en çok kabul gören McGhee'nin kuramı anahatlarıyla şu şekildedir:

McGhee'nin Mizah Gelişim Evreleri:

a. 1.Evre: Nesnelere Karşı Tutarsız Davranışlar (18-20 Ay)

b. 2.Evre: Nesnelerin ve Olayların Tutarsız Olarak Adlandırılması (20-24 Ay)

c. 3.Evre: Kavramsal Tutarsızlık (2-7 Yaş)

d. 4.Evre: Çoklu Anlamlar/Yetişkin Türü Mizah (7-11 yaş)

McGhee mizah kuramını bilişsel yeteneklere dayandırarak oluşturur. Bu evreler aynı zamanda Piaget'in bilişsel evreleriyle de yakından alakalıdır. McGhee 2002 yılında basılan 'Çocukların Mizah Gelişimini Anlamak ve Geliştirmek' (Understanding and Promoting the Development of Children's Humor) adlı kitabında bu evreleri oluştururken yaş sınırlarını koymuş olsa dahi bazı çocukların ilgili evreye daha erken ya da daha geç gireceğini belirtmiş̧tir. Ayrıca söz konusu mizahi formun en üst seviyeye ulaştı̆̆ dönem olduğunu da ifade etmiştir.

\section{Eğitim Öğretimde Mizahın Yeri ve Önemi}

Eğitim, insanların bilişsel ve ahlaki açıdan gelişmelerini sağlayan, onlara istendik davranışlar kazandıran, geleceğe hazırlanmaları için gerekli bilgileri onlara sunan bir süreci ifade etmektedir. Mizah da bu istendik davranışları onlara kazandırmada etkili bir araç olarak kullanılmaktadır. Başta yaratıcılık olmak üzere sosyal ilişkilerin kurulması ve düzenlemesi, 
rehberlik faaliyetleri içinde kullanılabilir olması, stresle başa çıkmada yardımcı olmasının yanında; temel dil becerilerinin kullanımındaki yetkinliklerin geliştirilmesinde de etkili bir vasıtadır. İletişim becerilerinin geliştirilmesinde ve olumlu öğrenme ortamlarının oluşturulmasında, mizah yoluyla düşündürmede, dersin daha eğlenceli hâle getirilmesinde ve ödüllendirmede mizah eğitim öğretimin vazgeçilmez bir aracıdır. Bu anlamda Türkçe eğitiminde mizah olgusuna şu bağlamda bakılabilir:

Türkçe öğretiminde mizahın öğrencilere kazandırdığı en önemli yeti şüphe yok ki zihinsel esneklik olgusudur. Bu becerinin kazandırıldığ 1 bireyler olaylara, durumlara farklı bir bakış açısıyla bakabilir, problem çözme becerisini kazanabilir. Çocukluğun ilk evrelerinden itibaren mizahla karşılaşmış olan bireylerin dil gelişiminin de bu mizahla tanışmamış bireylere nazaran daha iyi ve gelişmiş olacağı açıktır. Türkçe dersi öğrencilerin farklı metin türleriyle daha fazla ve yoğun olarak karşılaştığı bir derstir. İşte bu nedenle Türkçe dersinin ve dilin imkânları çocuklara mizah ögeleriyle daha fazla karşılaşma olanağı da sunmaktadır. Yine dil becerilerinin temel alındığı Türkçe dersi; öğrencilere imgesel düşünme, analitik düşünme, yaratıc1lı ve eleştirel düşünme gibi becerileri de kazandırma konusunda bir içeriğe sahip olduğundan mizah ögeleri bu düşünme becerilerinin bireylere kazandırılmasında yaygın ve etkin bir şekilde kullanılabilir.

Türkçe eğitimi; dil öğretimi, dinleme eğitimi, konuşma eğitimi, okuma, yazma eğitimi, medya okuryazarlığı, metin öğretimi, çocuk edebiyatı gibi daha birçok öğrenme ve beceri alanını ifade eden bir eğitim alanıdır. Böylesine geniş bir eğitim alanının başta bilişsel psikoloji olmak üzere edebiyat, sosyoloji, tarih ve daha birçok disiplinin kuram ve uygulamalarından bağımsız olması düşünülemez. Gelişim psikolojisinin önemli bir alanı olan mizah kavramı da bu anlamda Türkçe öğretiminin temel önermeleri için hayati önem taşımaktadır. Başta dil becerileri olmak üzere; bilişsel, duyuşsal ve devinişsel gelişim bağlamında mizah ve mizahi yapılara, öğrenme-öğretme ortamının bütün yapıları ve materyallerinde daha fazla yer verilmeli ve öğrencilerin mizah gelişimi desteklenmelidir. Türkçe öğretiminde mizah kullanımı alanında yapılan deneysel çalışmalar da bu savları destekler niteliktedir. Türkçe dersinde mizah kullanımının öğrencilerin tutum ve davranışları ile akademik başarılarına olumlu etki yaptığını, hayal gücünü geliştirip yaratıcıllğ̆ arıttırdığını ortaya koymuştur. Bununla birlikte, bu gelişimler doğrultusunda Türkçe dersi temel becerilerinden olan yazma ve konuşma becerilerinin de geliştiği saptanmıştır (Akben, 2018; Aydın, 2006; Şakiroğlu, 2018). Bununla birlikte yine de, Türkçe öğretiminde mizah kullanımına ilişkin yeterli çalışmanın olmadığı ve bu yönde bir bilinç ve farkındalık uyandırmanın da gerekli olduğu düşünülmektedir. Bu nedenle ve konunun bu yöndeki önemi doğrultusunda bu çalışma planlanmış, Türkçe öğretiminde, Türkçe ders kitapları örneğinde mizah unsurlarının varlığı araştırılmışır.

\section{Araştırmanın Amacı}

$\mathrm{Bu}$ çalışmanın amaçları şu şekilde sıralanabilir:

-Gelişim psikolojisinin önemli bir alanı olan mizah gelişiminin ne olduğunu açılamak,

-Türkçe öğretiminde kullanılan ders kitaplarında mizah unsurlarının ne yönde varlık bulduğunu araştırmak, 
-Türk edebiyatının mizah unsurları itibarıyla zengin geleneksel türlerinin Türkçe ders kitaplarında ne şekilde varlık bulduğunu tespit etmektir.

\section{Araştırmanın Yöntemi}

$\mathrm{Bu}$ çalışmada, Türkçe ders kitaplarında mizah unsurlarının ne yönde varlık bulduğu durumunu tespit etmek amacıyla yapılandırıldığından, betimleyici durum çalışması deseninde oluşturulmuştur (Merriam, 1998). Durum çalışması bir sistemin, dökümanlar, görseller-işitseller, raporlar araçları ile derinlemesine incelenmesi ve betimlenmesine dayanan nitel bir araştırma modelidir (Merriam, 2013; Creswell, 2007). Durum çalışmalarında, veri toplama aşamasında, dokümanlardan, arşiv kayıtlarından, görüşme ve gözlemlerden ve fiziksel yapılardan yararlanılabilir (Subaşı \& Okumuş, 2017; Yin, 1984). Bu çalışmada, dökümanlardan yararlanılmış, başka bir deyişle 2018-2019 eğitim-öğretim yılında okullarda ders kitabı olarak kullanılan Millî Eğitim Bakanlığ 15, 6, 7 ve 8. sınıf Türkçe ders kitapları veri toplama araçları olarak kullanılmıştır.

$\mathrm{Bu}$ bağlamda, doküman inceleme tekniği kullanılarak söz konusu kitaplardaki metinler, mizah unsurlarının varlığı ve ne şekilde bulunduğu açısından incelenmiştir. Doküman inceleme basılı ya da elektronik belgeleri gözden geçirmek, incelemek, taramak ve değerlendirmek için kullanılır (Bowen, 2009; Esendemir,\& Ertaş, 2018;Yanık \& Özdemir, 2017). Doküman incelemede asıl hedef araştırılması amaçlanan olgulara ilişkin veri içeren dökümanların inceleme, bilgi edinme ve anlamlandırma amacıyla analiz edilmesidir (Bowen, 2009; Corbin \& Strauss, 2008; Zorluoğlu vd., 2016). Döküman inceleme, hem bir veri toplama yöntemini hem de verilerin analiz edilme şeklinde ifade etmek için kullanılmakta ve araştırma verilerinin birincil kaynağı olan dokümanların toplanması, gözden geçirilmesi, incelenmesi, sorgulanması ve çözümlenmesi olarak tanımlanmaktadır (Bowen, 2019; O’leary, 2004, Özkan, 2019). Ders kitaplarında yer alan mizah unsurları değerlendirilirken fikra, alay/dalga geçme, taklit, hayali unsurlara yer verme/gerçek dışlık, uyaklı sözler ve geleneksel mizahi türler ile Türk mizah tipleri bağlamında ele alınmış ve incelenmiştir.

Nitelikli bir doküman incelemesinde konuya ilişkin belgelere ulaşıllp incelenmesi ve bu yönde gerekli düzenlemelerin yapılabilmesi gerekir (Karasar, 2007; Yıldırım \& Şimşek, 2013). Bu bağlamda 5-8.sınıf Türkçe ders kitapları incelenerek elde edilen veriler betimsel analiz yoluyla çözümlenmiş ve dikkatlere sunulmuştur. Veriler analiz edilirken eş araştırmacılar işe koşulmuştur. Elde edilen veriler iki araştırmacı tarafindan bağımsız analiz süreçlerine tabi tutulmuştur. Nitekim nitel veri analizinde deneyimli olan, dışarıdan bir araştırmacıdan faydalanmak çalışmaya katkı sağlayabilir (Yıldırım ve Şimşek, 2013).

Miles ve Huberman (1994), iyi bir nitel güvenirlik için kodlamanın güvenirliğinin en az \%80 uyum düzeyinde olması gerektiğini ifade eder. Bu nedenle iki araştırmacının analizleri için uyuşum yüzdesi (agreement percentage) formülü kullanılmıştır. Uyuşum yüzdesi; uyuşum miktarının 100 ile çarpımının, uyuşum miktarı ve uyuşmazlık miktarının toplamına bölünmesi ile elde edilir. Çalışmada, iki araştırmacı arasındaki uyuşum yüzdesi \%92 olarak hesaplanmıştır. Bu şekilde veri analizinin iyi bir güvenirlik yüzdesine sahip olduğu ortaya çıkmıştır. 


\section{Bulgular}

$\mathrm{Bu}$ bölümde araştırmanın veri kaynağında ele alınan ders kitaplarında okuma metinlerinde araştırmanın amacında ifade edilen mizahi ögelerin ders kitabı ünitelerinde ne kadar ve ne şekilde varlık bulduğu ele alınmıştır. Elde edilen bulgular hem tablolar şeklinde hem de içerik analizi yapılarak sunulmuştur.

\section{Beşinci Sınıf Ders Kitabına Ait Bulgular}

Tablo 1:Beşinci Sinıf Türkçe Ders Kitabında Mizahi Unsurların Varlı̆ğ

\begin{tabular}{|c|c|c|}
\hline Temalar & Metinler & Mizahın Varlığı \\
\hline \multirow{4}{*}{ Çocuk Dünyası } & Oyuncak & + \\
\hline & Çocukluk & + \\
\hline & Ben Bir Çınar Ağacıydım & + \\
\hline & Güneşin Uyuduğu Yer & - \\
\hline \multirow{4}{*}{ Millî Mücadele ve Atatürk } & Bilmeyen Var Mi? & + \\
\hline & Mustafa Kemal'in Kağnısı & - \\
\hline & 15 Temmuz & - \\
\hline & Küçük Ağa & - \\
\hline \multirow{4}{*}{ Erdemler } & Güvercin & + \\
\hline & Karagöz ile Hacivat & + \\
\hline & Püf Noktası & - \\
\hline & Vakit Varken & - \\
\hline \multirow{4}{*}{ Bilim ve Teknoloji } & Uzayda Bir Gün & + \\
\hline & Sarımsak Soslu Makarna & - \\
\hline & Bir Dâhiyle Konuşmak & - \\
\hline & Jules Verne'den Geleceğe Dair & + \\
\hline \multirow{4}{*}{ Millî Kültürümüz } & Anadolu Sevgisi & - \\
\hline & Forsa & - \\
\hline & Tamburi Cemil Bey Enstrümanları Anlatıyor & - \\
\hline & Çocuk Doğru Söyledi & + \\
\hline \multirow{4}{*}{ Okuma Kültürü } & Okuma Kitaplarım & + \\
\hline & Kitabın Serüveni & - \\
\hline & Karikatür & + \\
\hline & Keramet Kavukta mı? & + \\
\hline \multirow{4}{*}{ Sağlık ve Spor } & Anadolu'nun Cirit Oyunları & - \\
\hline & Sağlıklı Yaşıyorum & - \\
\hline & Cazgir & - \\
\hline & Hasta & - \\
\hline \multirow{4}{*}{ Doğa ve Evren } & Yüksek Evde Oturanın Türküsü & - \\
\hline & Reçete & - \\
\hline & Kar Tanesinin Serüveni & + \\
\hline & Eyvah! Ormanda Kayboldum! & - \\
\hline
\end{tabular}

Çocuk Dünyası temasında 'Oyuncak' adlı metinde yansılamalı sözler, uyaklı tekrarlar, kişileştirme/konuşturma yoluyla oluşturulmuş mizah yapıları yer almıştır. ‘Çocukluk' şiiri çocukluğa özlem teması üzerine oluşturulmuş bununla beraber metin 
etrafında kullanılan görseller çocukluk hatıralarının gülünç boyutlarını ifade eden görseller yer almıştır. 'Ben Bir Çınar Ağacıydım' metni doğrudan doğruya gerek görsel unsurları gerekse metnin içeriği açısından kişileştirme/konuşturma yoluyla mizah yapılarının yer aldığı bir metin olarak düzenlenmiştir.

Millî Mücadele ve Atatürk temasında 'Bilmeyen Var M1?' adlı metin görsel unsurlarıyla mizah yapılarını barındırmakta ayrıca mizahın düşündürme unsurunu da kapsamaktadır. Özellikle anlamlı ve düşündürücü zarif söz olarak adlandırılan nükte unsuru bu metinde önemli ölçüde yer almıştır. Dil cambazlı̆̆ı, çift anlamlılık gibi nükte yapma unsurlarına yer verilmiş, ayrıca karikatürlerle de metin desteklenmiştir. Beydaba'nın Kelile ve Dimne'sinden alınan 'Güvercin' adlı metin anekdotlarında barındırdığı düşündürücü komik unsurlarıyla dikkat çekmektedir. Doğrudan mizahi bir form taşımasa da iletisinde yer alan dayanışma ve paylaşma olgusuna dair atıflarda mizah ögelerinden yararlanılmıştır. Geleneksel halk tiyatrosunun en önemli türlerinden olan Karagöz ile Hacivat metninde temizlik ve görgü kuralları muhavere ve diyalog bölümlerinde mizah ögelerinden yararlanarak ortaya konmuştur. Mizahın dikkat çeken ve düşünceyi harekete geçiren özelliği bu bölümlerde yoğun olarak ele alınmıştır.

Uzayda Bir Gün, Jules Verne'den Geleceğe Dair, Çocuk Doğru Söyledi, Okuma Kitaplarım, Keramet Kavukta mı?, Kar Tanesinin Serüveni adlı metinlerde mizah şu unsurları geliştirici bağlamda ele alınmış ve metinlerde yer bulmuştur: Çocukların iç görüsünü artırma, yaratıc1lıklarını destekleme, asıl söylenmek istenen düşünceyi simgesel anlatımla verebilme, kişiler arası iletişimi geliştirme ve sosyal etkileşimi hızlandırma. Bunlar ele alınırken özellikle metinlerin diyalog bölümlerinde tezatlardan, uyumsuzluklardan, kinayeli sözlerden yararlanılmış; ayrıca bu olguları destekleyici görsellere de yer verilmiştir. Özellikle 'Karikatür' adlı metin doğrudan mizah unsurunun bu yapıtaşına ayrılmıştır. Karikatürler; mizah unsurunun ve mizah yoğunluğunun üst düzeyde olduğu materyallerdir. Doğala ters düşen insan düşünce ve eylemlerinin gülünç yanları karikatürler vasıtasıyla aktarliır.

Beşinci sınıf Türkçe ders kitabı 'Çocuk Dünyası, Millî Mücadele ve Atatürk, Erdemler, Bilim ve Teknoloji, Millî Kültürümüz, Okuma Kültürü, Sağlık ve Spor, Doğa ve Evren' temalarından oluşmaktadır. Bütün temalarda mizahi ögelere yer verilmiş olup yer verilen mizah yapıları hem eğlendirmeye hem de olumlu davranış kazandırmaya yönelik ele alınmıştır. 


\section{Altıncı Sınıf Ders Kitabına Ait Bulgular}

Tablo 2: Altıncı Sınıf Türkçe Ders Kitabında Mizahi Unsurların Varlığı

\begin{tabular}{|c|c|c|}
\hline Temalar & Metinler & Mizahın Varlığı \\
\hline \multirow{4}{*}{ Erdemler } & Forsa & - \\
\hline & Kaynatılmış Tohum & + \\
\hline & Ceylana Yardım Edenler & + \\
\hline & Dostluk & - \\
\hline \multirow{4}{*}{ Millî Kültürümüz } & Nevruz & - \\
\hline & Türküler Dolusu & - \\
\hline & Boş Bir Kümes, Birkaç Dolu Kalp & + \\
\hline & $\begin{array}{l}\text { Önce İğneyi Kendine Batır, Sonra Çuvaldızı } \\
\text { Ele }\end{array}$ & + \\
\hline \multirow{4}{*}{ Millî Mücadele ve Atatürk } & Atatürk orman Çiftliği & - \\
\hline & Atatürk Geometri Kitab1 & - \\
\hline & 30 Ağustos & - \\
\hline & Dolunayda Kurtlar & - \\
\hline \multirow{4}{*}{ Çocuk Dünyası } & Nasrettin Hoca F1kraları & + \\
\hline & Ben Kimim? & + \\
\hline & Bilmece & + \\
\hline & Çocuk ve Resim & - \\
\hline \multirow{4}{*}{ Birey ve Toplum } & Birlikte & - \\
\hline & Geri Kazanım & - \\
\hline & Ömür Törpüsü & + \\
\hline & Değerlere Uymada Üç Hata & + \\
\hline \multirow{4}{*}{ İletişim } & Güler Yüze ve Gülmeye Dair & + \\
\hline & Teknolojik Bayram Kutlamaları & + \\
\hline & Pulsuz Dilekçe & - \\
\hline & Bilinçli Medya Tüketimi & + \\
\hline \multirow{4}{*}{ Doğa ve Evren } & Uzaklar & - \\
\hline & Gezegenimiz Isınıyor & - \\
\hline & Orman & - \\
\hline & Gün Doğuyor & - \\
\hline \multirow{4}{*}{ Bilim ve Teknoloji } & Uçakta Yolculuk & - \\
\hline & Robotik ve Enerji & + \\
\hline & Newton'un Elmas1 & + \\
\hline & Mikrop Savaşları & - \\
\hline
\end{tabular}

Mizahi öyküler, öykülerde güldürücü özelliklerin yer aldığı metinlerdir. Erdemler temasında yer alan 'Kaynatılmış', 'Tohum' ve fabl şeklinde yapılandırılmış olan 'Ceylana Yardım Edenler' metinlerinde mizahi öykünün sınırlarına yer yer yaklaşılmış, mizah duygusunun geliştirilmesine yardımcı olabilecek olgulara, söz oyunlarına, kalıp sözlere yer verilmiştir. 'Boş Bir Kümes, Birkaç Dolu Kalp' metninde ise “...evin erkeği Türkçe bir şeyler söyledi. Almanlar anlamadılar; onlar da Almanca dertlerini anlattı, bu sefer de bizim Türk anlamadı." eğlendirici ve gülümsetici ögelere yer verilmiştir. Bir kalıp sözün aynı zamanda başlık olarak kullanıldığı 'Önce İğneyi Kendine Batır, Sonra Çuvaldızı Ele’ adlı 
okuma parçasında hiciv/yergi olguları ustalıkla işlenmiştir. Zira hiciv, bir toplumu, bir düşünceyi, bir nesneyi veya bir göreneği yermek için yazılmış yazı veya söylenmiş söz, taşlama şeklinde belirtilmiştir. En yaygın mizah türlerinden biri olan hiciv kelime ve kelime oyunları ile gerçekleştirilir. Nasrettin Hoca Fıkraları'nda metnin hazırlık bölümünde doğrudan güldürü ve karikatür olgusuyla öğrenciler tanıştırılmış, geleneksel mizah kodlarımızı ortaya koyan metinler ele alınmıştır. 'Ben Kimim' metninde fablların imkânları içinde mizah ögelerine gerek diyalog gerekse görsellerle yer verilmiştir. Bir Karagöz metni olan 'Bilmece'de türün geleneksel formu içinde yer alan yanlış anlaşılmalar bağlamında mizahi unsurlara çokça yer verilmiştir. 'Ömür Törpüsü, Değerlere Uymada Üç Hata, Güler Yüze ve Gülmeye Dair, Teknolojik Bayram Kutlamaları, Bilinçli Medya Tüketimi, Robotik ve Enerji, Newton'un Elması' metinleri de mizah yapılarının kullanıldığı okuma parçalarıdır. Özellikle İletişim, Bilim ve Teknoloji temalarında yer alan metinlerde ironinin sınırlarında dolaşılmıştır. Birtakım olguları ya da eserleri alaycı bir anlatımla söz konusu etmek şeklinde ifade edilebilecek olan ironinin bir mizah unsuru olarak metinlerde yer alması bu anlamda değerlidir. 6. Sınıf Türkçe ders kitabının Millî Mücadele ve Atatürk temasında yer alan metinlerde mizah yapılarına yer verilmediği görülmüştür.

\section{Sinıf Ders Kitabına Ait Bulgular}

Tablo 3: Yedinci Sınıf Türkçe Ders Kitabında Mizahi Unsurların Varlı̆̆ı

\begin{tabular}{|c|c|c|}
\hline Temalar & Metinler & Mizahın Varlığı \\
\hline \multirow{4}{*}{ Erdemler } & Mor Salkımlı Ev & - \\
\hline & Sevgi Kurtaracak Bizi & - \\
\hline & Kırmızı Pabuçlar & + \\
\hline & İki anı & + \\
\hline \multirow{4}{*}{ Doğa ve Evren } & Yerçekimsiz Yaşam & + \\
\hline & Rüzgâr & - \\
\hline & Yeşil Gözlü Kardan adam & + \\
\hline & Beyaz Gemi & - \\
\hline \multirow{4}{*}{ Millî Kültürümüz } & Ülkemin Renkli Haritası & + \\
\hline & Dünyayı Güldüren adam & + \\
\hline & Bayrak & - \\
\hline & Anadolu'da Kilim Demek & - \\
\hline \multirow{4}{*}{ Millî Mücadele ve Atatürk } & İstanbul Liseli Küçük Hasan & - \\
\hline & Atatürk'ün Kişiliği ve Özellikleri & - \\
\hline & $\begin{array}{l}15 \text { Temmuz Şehitlerinin Adları Okullarda } \\
\text { Yaşatılıyor }\end{array}$ & - \\
\hline & Samsun Yolculuğuna Hazırlık & - \\
\hline \multirow{4}{*}{ Vatandaşlık } & Ak Sakallı Bilge Dede & + \\
\hline & Sorumluluklarımız & - \\
\hline & Harman Yerinde & - \\
\hline & Vaktini Boş Geçirme & + \\
\hline \multirow{4}{*}{ Sağlık ve Spor } & Goool! & + \\
\hline & Benim Adım: Şeker Çocuk & + \\
\hline & Yeterli ve Dengeli Beslenme & - \\
\hline & İyi Uykular... Tatlı Rüyalar & + \\
\hline
\end{tabular}




\begin{tabular}{lll}
\hline \multirow{3}{*}{ Sanat } & Belkıs Tiyatrosu & + \\
\cline { 2 - 3 } & Geleneksel El Sanatları Çarşısı & - \\
\cline { 2 - 3 } & Ay Şairi & - \\
\cline { 2 - 3 } & Leyla Gencer & + \\
\hline \multirow{3}{*}{ Bilim ve Teknoloji } & Buluşa Doğru & - \\
\cline { 2 - 3 } & Kara Tren & - \\
\cline { 2 - 3 } & $\begin{array}{l}\text { Medya Yalnızca Televizyon ve Gazeteden } \\
\text { İbaret Değildir }\end{array}$ & + \\
\cline { 2 - 3 } & Ĭğnenin Deliği & + \\
\hline
\end{tabular}

7. sınıf ders kitabında Erdemler adlı ilk temada 'Kırmızı Pabuçlar' metni öykülemenin imkânlarından yararlanarak bireyi geliştirici ve olumlu düşüncelere sevk edici mizah ögeleri barındırmaktadır. Yer yer imgesel bir anlatımının işe koşulduğu metinde benzetme ve tezatlarda bu mizah yapısı sağlanarak verilmiştir. Yine çocuk duyarlılığıyla kaleme alınmıs ola ‘'̇ki Anı' okuma metninde de deyim ve atasözlerinin mizahi yapıları gözlenmiştir. Özellikle atasözlerinin birbirleriyle olan karşıtlıklarından yararlanılmış 'eğri otur doğru konuş' atasözüyle beraber 'doğru söyleyeni dokuz köyden kovarlar' ifadesi yer almıştır. Yine 'taşıma suyla değirmen dönmez' sözü karşııtlıkla, 'damlaya damlaya göl olur' sözüyle ifade edilmiştir. Bununla beraber masalsı bir anlatımla oluşturulmuş olan metinde fabl unsurlarından da yararlanılmış; kişileştirme ve konuşturmalara yer verilmiş̧ir.

'Ülkemin Renkli Haritaları' metni gerek içerik bilgisi gerekse kullanılan görseller açısından mizah unsurlarının istendik yönde kazandırılması bağlamında ele alınmıştır. Diyaloglar, monologlar, benzetme ve kişileştirme unsurları yoğun olarak kullanılmış eğitimde hedeflenen bireysel ve sosyal gelişime göre düzenlenmiştir. Zihinsel esnekliğin ortaya konduğu metinde çeşitli uyarana birçok perspektiften bakabilme olanağı oluşturulmuştur denilebilir. Zihinsel esneklik nükte demektir, nükte imgeseldir onun için zihinsel esneklik ile ifade edilir. Bir diğer metin olan 'Dünyayı Güldüren Adam'da ise Nasrettin Hoca ve fikraları ele alınmıştır. Türk sözlü edebiyat geleneğinin en eski türlerinden biri olan fikralar, geleneksel mizah anlayışımızın da önemli yapı taşlarındandır. Tarihî bir şahsiyet olan Nasrettin Hoca'nın da ders kitabında yer alması ayrıca önemlidir. Nasrettin Hoca Uluslararası bir fikra tipine dönüşmüş durumdadır. Türk dünyasında pek çok Türk boyu onun kendi aralarından çıkmış ve yaşamış bir kişilik olduğuna inanacak kadar benimsemiştir. Vatandaşllk temasında yer alan 'Ak Sakallı Bilge Dede' metninde bireyin mizahı kendisine katkı sağlamak amacıyla ve başkalarına zarar vermeyecek biçimde, kendini geliştirici mizah şeklinde kullanıldığı bulgulara yansımıştır. 'Vaktini Boş Geçirme' şiirinde ise söz tekrarları ve uyaklı ifadeler yoluyla oluşturulmuş eğlendirici ögeler söz konusundur. Sağllk ve Spor temasında yer alan 'Goool!, Benim Adım: Şeker Çocuk, İyi Uykular..Tatlı Rüyalar' metinlerinde ise eğlendirirken öğreten, düşündüren ve öğrencilerde öğrenme etkinliklerine karşı olumlu tutum geliştirmelerine yardımcı olacak şekilde mizah unsurlarına yer verilmiştir. 'Belkıs Tiyatrosu' okuma metninde masal unsurlarından yararlanmış, karikatürlerle mizah yapıları desteklenmiştir. 'Buluşa Doğru' metninde mizahın önemli bir aracı olan karikatürlere yer verilmişken 'Iğnenin Deliği’ metninde ise diyalog, monolog yapılarında mizahi ögelere yer verilmiştir.

Mizahta her şeyden önce paylaşımın olduğu açıktır. Paylaşımcılık ise güvensizlik duygusunun aşılmasında bir davranış biçimi olarak yadsınamaz bir yere sahiptir. 
Paylaşımcılığın birliktelik, içtenlik, arkadaşlık ve dostluk duygularının güçlenmesindeki önemi, dahası mizahın farklı kültürlerin birbiri anlamasında da bir köprü görevi üstlenebileceği gözden kaçırılmamalıdır (Topçuoğlu, 2007). Sosyal gelişimin önemli bir evresi olan 7. Sınıf aynı zamanda bireyin kendini bir gruba dâhil olma duygusunun da güçlendiği bir gelişim dönemini ifade etmektedir. Bu anlamda 7. Sınıf ders kitabında mizah yapılarının yeterince yer bulduğu ve mizah ögelerinin başarıyla kullanıldığı ifade edilebilir. Bununla beraber Millî Mücadele ve Atatürk temasında mizah ögelerine yer verilmemiştir.

\section{Sekizinci Sınıf Ders Kitabına Ait Bulgular}

Tablo 4. Sekizinci Sinıf Türkçe Ders Kitabında Mizahi Unsurların Varlı̆ğ

\begin{tabular}{|c|c|c|}
\hline Temalar & Metinler & Mizahın Varlı̆ı \\
\hline \multirow{4}{*}{ Kişisel Gelişim } & Benlik Üzerine & - \\
\hline & Martı & - \\
\hline & Acele Karar Vermeyin & - \\
\hline & Bir Adım Atın & - \\
\hline \multirow{4}{*}{ Millî Mücadele ve Atatürk } & Vatan yahut Silistre & - \\
\hline & O Geliyor & - \\
\hline & İstiklal Madalyası & - \\
\hline & Atatürk’e Mektup & - \\
\hline \multirow{4}{*}{ Birey ve Toplum } & Faydalı Bir İş Görmek Zevki & + \\
\hline & Gurbet & - \\
\hline & Türkçenin Güzelliği & - \\
\hline & Yirmi Beş Kuruş & + \\
\hline \multirow{4}{*}{ Sanat } & Sanat & - \\
\hline & Mikro Minyatür & - \\
\hline & Selimiye Camisi & - \\
\hline & Bir Baba/Bir Zihniyet & - \\
\hline \multirow{4}{*}{ Millî Külttürümüz } & Anadolu Uygarlıkları & - \\
\hline & Burada Dur & - \\
\hline & Ergenekon Destan1 & - \\
\hline & Anadolu Davulu & + \\
\hline \multirow{4}{*}{ Zaman ve Mekân } & Kalbin Sesi & - \\
\hline & Geçen Zaman & - \\
\hline & Değirmende Döner Taşım & - \\
\hline & Bursa'da Zaman & - \\
\hline \multirow{4}{*}{ Erdemler } & Yunus Emre'nin Mezarı & - \\
\hline & Gülü İncitme Gönül & - \\
\hline & Emine Teyze'nin Çilek Reçeli & - \\
\hline & Eşekle Tilki & + \\
\hline \multirow{4}{*}{ Hak ve Özgürlükler } & Bilge Adamın Yolu & - \\
\hline & Aliya İzzet Begoviç ve Özgürlük Mücadelesi & - \\
\hline & Özgürlük & - \\
\hline & Haritada Bir Nokta & + \\
\hline
\end{tabular}


Mizah, çocukların entelektüel, toplumsal, duygusal, zihinsel ve kişilik gelişimlerini kolaylaştırmada güçlü bir rol oynadığı için önerilmekte (McGhee, 2002) ve bununla ilgili çalışmalar da artarak devam etmektedir. Gerçek anlamda iyi bir mizah bilincine sahip olmak başta olumsuz durumlarla başa çıkma, sosyal uyumu kolaylaştırma gibi birçok yararlı durumu da beraberinde getirecektir. Gelişim olarak artık ilk gençlik yıllarının hemen başında olan 8. Sınıflar için hazırlanmış olan ders kitabı mizah yapılarını ihtiva etmek konusunda yukarıda ifade edilen becerilerin gelişmesinde/geliştirilmesinde diğer ders kitaplarının gerisinde kalmaktadır.

Kişisel Gelişim adlı birinci temada yer alan metinlerde mizahi bir yapıya rastlanmamıştır. Oysa 'kişisel gelişim' olarak ifade edilen bu temada mizah gelişimini destekleyecek yapıtaşlarına yer verilmesi uygun olacak, ifade edilen zihinsel ve kişilik gelişimlerine yardımcı olabilecek bir enstrüman olarak kullanılması doğru olacaktı. İkinci tema olan 'Millî Mücadele ve Atatürk' temasında yer alan metinlerde de hiç mizah unsuruna rastlanmamıştır. Birey ve Toplum temasında yer alan 'Faydalı Bir İş Görme Zevki' adlı metnin görsel unsurlarında karikatürlere yer verilmiş, son okuma parçası olan 'Yirmi Beş Kuruş' metninde ise gülme eyleminin düşünce merkezli olan yönünü ifade eden bir tarzına rastlanmıştır. Sanat temasında okuma metinleri içinde mizahi ögeler, 'Anadolu Davulu' adlı metinde davulcu manileri olarak ifade edilen nazım formunda karşımıza çıkmaktadır. 'Tohumu at da gel/Arpa buğday sat da gel/Uyan hey ağam uyan/Orucunu tut da gel' manisiyle beraber yine 'Eğlenip gülüşelim/Tanışıp bilişelim/Bahşişini hazırla/Bayramda görüşelim' manileri bu anlamda örnek gösterilebilir. Nitekim söz tekrarlarının ve uyaklı ifadelerin çocuğu eğlendiren bir tarafının olduğu ve bu türden metinlere çocuk edebiyatının türleri içinde yer verildiği bilinmektedir. Özellikle bazı şiirlerin çocuğun eğlenme ihtiyacına göre oluşturulduğu ve çocuk duyarlılığını yansıttığı çocuk edebiyatı araştırmacılarının vurguladığı bir durumdur. Zaman ve Mekân temasinda yer alan okuma metinlerinde mizah ögelerine hiç rastlanmazken, Erdemler temasında fabl türündeki 'Eşekle Tilki' metni bu ders kitabının mizah ögesinin en yoğun olduğu metin olarak karşımıza çıkmaktadır. Fablların çıkış noktası insanları incitmeden onlara ahlak dersi vermektir. Atasözleri gibi tecrübe ve bilgelik yüklüdürler, ancak onlardan daha etkili oldukları söylenebilir. Öğrenciler, kendilerine verilen direkt öğütlerden rahatsızlık duymaktadırlar. Fabllarda öğütler direkt verilmediğinden, bu ögütlerin okuyucular tarafindan daha kolay kabullenilmeleri söz konusudur (Erdal vd, 2011). Hak ve Özgürlükler temasında ise mizahi düşünme duyuş ve düşünüş tarzına ait ögeler 'Haritada Bir Nokta' adlı öykü parçasında konuşturma, tezatlardan yararlanma şeklinde karşımıza çıkmaktadır. Kişisel Gelişim, Sanat, Zaman ve Mekân temalarında yer alan metinlerde mizah ögelerine rastlanmamıştır.

\section{Geleneksel Mizah Türlerine Dair Bulgular}

$\mathrm{Bu}$ araştırmanın önemi; mizah üzerine yapılan diğer araştırma ve incelemelerden farklı olarak Türk yazınının içerisinde mizah barındıran geleneksel türlere ve mizahi tiplere Türkçe öğretiminde ne kadar yer verildiği ve bunların metinlere ne kadar yansımış olduğunun araştırılmasından gelmektedir. Başta geleneksel şiir formları olmak üzere, konuşmalık türler olan atasözü, deyim, bilmece, alkış-kargış, tekerleme; söylemelik türler; türkü, ağıt, ninni ve mani; anlatmalık türler, seyirlik türler olan; köy seyirlik oyunları, Karagöz, kukla, meddah, ortaoyunu gibi türlerle beraber; özellikle mizah deyince akla ilk 
gelen fikra türü içerisinde yer alan Türk fikra tipleri; Nasrettin Hoca, İncili Çavuş, Bekri Mustafa, Bektaşi, Ahmet Akay, Aldar Köse, Temel gibi Türk fikra tiplerinin Türkçe öğretimindeki varlığı araştırılmıştır.

Tablo 5. Geleneksel Mizah Türlerinin Türkçe Kitaplarındaki Varlı̆̆ı

\begin{tabular}{lll}
\hline $\mathbf{1}$ & Atasözü & + \\
$\mathbf{2}$ & Deyim & + \\
\hline $\mathbf{3}$ & Alkış-kargiş & - \\
\hline $\mathbf{4}$ & Türkü & - \\
\hline $\mathbf{5}$ & Ninni & - \\
\hline $\mathbf{6}$ & Mani & + \\
\hline $\mathbf{7}$ & Köy seyirlik oyunları & - \\
\hline $\mathbf{8}$ & Karagöz & + \\
\hline $\mathbf{9}$ & Kukla & - \\
\hline $\mathbf{1 0}$ & Meddah & - \\
\hline $\mathbf{1 1}$ & Ortaoyunu & - \\
\hline $\mathbf{1 2}$ & Fikra & + \\
\hline
\end{tabular}

Yapılan araştırmada geleneksel türler içinde kitaplarda atasözü ve deyim varlığ içinde yer alan mizahi olgulara yer verildiği görülmüş hatta bunların bazı metinlerin adı olduğu tespit edilmiştir; 'Önce İğneyi Kendine Batır, Sonra Çuvaldızı Ele' metni bunun en bariz örneği olarak karşımıza çıkmaktadır. Mani türünün mizah ögesi barındırın metinleri yine ders kitaplarında yer bulmuştur. 'Anadolu Davulu' metninde yer alan davulcu manilerinin içeriği bunu örneklendirmektedir. Tekerlemeler, Karagöz, Nasrettin Hoca fikraları da yine ders kitaplarında yer alan geleneksel mizahın yapıları olarak kitaplarda yer almıştır. Bunlarla beraber mizah yapılarının çokça olduğu alkış-kargış, türkü, ninni, ortaoyunu, köy seyirlik oyunları, kukla ve meddah gibi türlerden yararlanılmadığı görülmüştür.

Bulgular genel olarak şu şekilde özetlenebilir:

1. Türkçe ders kitaplarında (5-8) mizah ögeleri ihtiva eden metinler bütün ünitelerde değil daha çok 'Çocuk Dünyası', 'Millî Kültürümüz', 'Birey ve Toplum' gibi temalarda yoğunlaşmıştır.

2. Mizahi yapıları barındırması yönünden nicelik olarak dağılım her düzeydeki ders kitabında farklıdır. 5. sınıf ders kitabında 13; 6 ve 7. sınıflarda 14 metinde mizahi ögelere rastlanırken 8. Sınıf ders kitabında sadece 5 metinde mizahi ögelere yer verilmiştir.

3. Kitaplarda yazılı ve görsel mizah ögeleri bir arada kullanılmış olsa dahi yazılı mizah ögeleri daha ağır basmaktadır.

4. Görsel mizah ögelerinden en fazla malzeme karikatür ve resimler şeklinde görülmektedir.

5. Yazılı mizah ögeleri anlatmaya dayalı, söylemelik, konuşmalık türler içerisinde yer almakta; atasözü, deyim, kinayeli ifadeler, zıtlıklar, abartmalar gibi ögelerle de kendini göstermektedir.

6. Mizah unsurları Geleneksel Türk tiyatrosu içerinde Karagöz'de, diğer türler içerisinde ise fikra, öykü gibi yapılarda bulunmaktadır. Araştırmanın bu aşaması için düşünülen geleneksel türlerdeki mizahın tespit edilmesinde birçok tür gözlemlenememiş; 
kukla gibi türler ise mizah özelliklerinin yansıtıldığı oyunlar şeklinde değil, tür hususiyetlerinin açıklandığı metinler olarak kitaplarda yer bulmuştur.

7. Mizahi yapıların bulundukları metinler, mizah tarzlarından kendini geliştirici ve katılımcı yani olumlu mizah yönündedir.

8. Türk fikra tiplerinden sadece Nasrettin Hoca mizah unsuru içerisinde yer bulmuş, diğer fikra tiplerine hiç yer verilmemiştir.

\section{Sonuç ve Tartışma}

$\mathrm{Bu}$ bölümde, eğitim öğretim ortamlarında mizah kullanımına ve etkilerine ilişkin çalışma bulguları ve sonuçları ile genelde dil öğretimi ve özelde Türkçe öğretiminde mizah kullanımı ile ilgili yapılmış olan çalışmalar ele alınacak ve bu çalışmalara ilişkin tartışmalar ışığında, bizim çalışmamız değerlendirilerek sonuçlandırılacaktır.

Gelişim psikolojisinin önemli bir boyutunu oluşturan mizah gelişimi, eğitim ortamının da önemli değişkenlerinden biridir. Başka bir deyişle, mizahi bir anlatımı benimseyen bir öğretmen ya da mizahtan yararlanarak yapılandırılan bir öğrenme-öğretme ortamı, eğitim ortamının önemli değişkenlerdendir. Nitekim günümüzde mizahi bir zekâya sahip olmanın bir üstünlük olarak kabul edilme durumu da söz konusudur. Bununla beraber mizahın çeşitli düşünme becerilerini özellikle yaratıcı düşünme becerisini geliştirdiği, yaratıcı düşünen bireylerin mizah yeteneği olduğu da vurgulanan bir durumdur. Aynı zamanda mizah eğlendirmek, güldürmek gibi işlevlerinin yanında duyuşsal, bilişsel ve sosyal gelişim açısından önemlidir.

Öğrenme-öğretme ortamlarında mizahtan yararlanmanın bu sürece olumlu etki ettiğini ifade eden birçok çalışma bulunmaktadır. Başta motivasyon olmak üzere dikkat, derse karşı olumlu tutum geliştirme, estetik bir duyuş ve düşünüş geliştirme konusunda fayda sağlayacağı açıktır. İletişim becerilerinin geliştirilmesinin yanında problem çözme becerisinin de içinde olduğu daha birçok olumlu yanından söz edilebilir (Bolkan vd., 2018; Schatz \& LoSchiavo, 2006; Summerfelt, 2010; Vance, 1987; Wanzer vd., 2010) Kırk yıl süren mizah araştırmalarını incelemesinde Banas (2011), mizah ve eğitimle ilgili en net bulguların, öğrenme ortamı yaratmak için mizah kullanımını ilgilendirdiğini belirtmiş̧ir. Olumlu, saldırgan olmayan mizahın kullanılması, daha ilginç ve rahat bir öğrenme ortamı, daha yüksek eğitmen değerlendirmeleri, daha yüksek motivasyon ve dersten keyif alma durumları ile ilişkilendirilmiştir (Banas, vd. 2011). Mizah, bir eğitmen ile öğrenci arasındaki psikolojik mesafeyi azaltma yeteneğine sahiptir. Aylor ve Opplinger (2003), yaptıkları çalışmada mizahın bir eğitmenin yaklaşılabilir, erişilebilir, iletişim kurulabilir olduğu hissine katkıda bulunduğunu keşfetmişlerdir. Etkileşimdeki artışın sonucunda da öğrenci ile öğretmen arasında daha anlamlı ilişkiler geliştirilmektedir. Bu da öğrenme ortamlarına olumlu yönde katkı yapan, öğrencilerin derse ve okula karşı olumlu tutum geliştirmelerini sağlayan bir unsurdur. Bu bağlamda, hem temel hem de üst düzey düşünme becerilerini geliştirme anlamında hem de ders saatleri düşünüldüğünde temel derslerden biri olan Türkçe derslerinde, öğrencilerin okula ve derslere olumlu tutum geliştirecek, öğretmen-öğrenci ilişkisini olumlu yönde etkileyecek ve genel olarak motivasyonu artıracak mizah unsurlarından faydalanmanın eğitim öğretim ortamlarına önemli katkılarının olacağın düşünülmektedir. 
Mizahın ilgiyi ve dikkati de arttırdığı çalışmalar soncunda bulunmuştur. Örneğin, Berlyne (1972) tarafindan yapılan araştırmaya göre, mizah gibi bir insanın beklentilerini bozan ya da şaşırtan herhangi bir şey psikolojik uyarılmaya neden olabilir. Bu, dikkatsiz bir öğrenciyi, orta derecede özenli bir öğrenciye dönüştürerek performansı kolaylaştırır. Bu bağlamda, dinleme ve okuma gibi dikkat gerektiren becerilerin geliştirilmesinin hedeflendiği Türkçe derslerinde, uzun metinleri okuma ve izlediğini/dinlediğini anlama konusunda mizahtan yararlanılması, bu alandaki gelişime katkıda bulunabilir.

Mizah hatırlamayı geliştirir ve öğrenmeye yardımcı olur. Eğitim-öğretim ortamlarına mizah unsurunu katmak, hatıllamaya yardımcı olma potansiyeline sahiptir. Örneğin, Schmidt (2002), çalışmasında laboratuvar deneylerinde öğrenciler mizahi yolla verilen bilgiyi daha iyi hatırladıklarını ortaya çıkarmıştır. Türkçe derslerinde de hatırlaması ve ögrenme zor olan konularda (dilbilgisi konuları, yazım noktalama ile ilgili kurallar vb.) mizahtan faydalanmanın bu alanda öğrenilen bilgilerin kalıcılığını sağlayabilir.

Ziv tarafindan yapılan iki çalışmada mizah kullanımının farklı düşüncelerin üretilmesini ve fikir ayrılıklarının ortaya çıkmasını sağladığı tespit edilmiştir. Ziv, daha sonra bunu teori hâline getirerek, mizahın eğlenceli bir ruh hâli, ortam ve çevre yarattığından olağandışı öğretimi teşvik ettiğini saptamıştır. Ayrıca Ziv, çalışmasında mizahın kullanıldığı derslerin sonucunda yapılan sınavlarda öğrenci notlarının, mizahın kullanılmadığı derslerin sonunda yapılan sınavlara göre daha yüksek olduğunu bulgulamıştır (Ziv, 1983; Ziv, 1988). $\mathrm{Bu}$ bağlamda, farklı fikirleri tartışma ve ifade etme imkânın bulunduğu ve aslında bu becerilerin geliştirilmesinin hedeflendiği Türkçe derslerinde, mizah kullanımının hem amaç hem de düşünce üretme, ortaya koyma süreçlerinde keyifli bir araç olarak kullanılmasının faydalı olacağı düşünülmektedir.

Kılınç (2008) çalışmasında, öğretimde mizahi kavramaya dayalı bir materyal geliştirmenin öğrencilerin başarı ve tutumlarını olumlu yönde etkilediğini ortay çıkarmıştır. Ayrıca öğrenciler bu öğretim sürecini 'eğlenceli-zevkli', 'görsel', 'kalıcılı̆̆ı yüksek', 'derse katılım yükssek', 'yapılandırmacı', 'yaratııı' şeklinde değerlendirmişlerdir. Aynı şekilde Oruç (2006) çalışmasında, sosyal bilgiler dersinde mizah kullanılan deney grubu öğrencileri ile kontrol grubu öğrencilerinin akademik başarı ve Sosyal Bilgiler dersi tutumları arasında deney grubu lehine anlamlı farklılıklar ortaya çıkarmıştır. Aydın (2006), Türkçe dersinde mizah kullanımının öğrenci tutum ve başarısına etkisini araştırdığ çalışmasında mizah kullanımının öğrencilerin akademik başarı ve mizaha yönelik tutumlarına olumlu yönde etki yaptığı sonucuna ulaşmıştır. Akben (2018), çalışmasında, mizah kullanımının yaratıcılığı arttırdığını tespit etmiştir. Ayrıca, kişilik özellikleriyle ilişkili olmayan mizah tarzlarının, ilgili kişilik özelliğinin yaratıcılık üzerindeki etkisini güçlendirdiği saptamıştır. Şakiroğlu (2018), mizah temelli etkinliklerin Türkçe derslerinde uygulanmasını konu alan araştırması sonucunda, mizah temelli etkinlikler ile Türkçe dersi gören deney grubundaki öğrencilerin anlatma (konuşma ve yazma) becerileri son test puanlarının, kontrol grubunda yer alan ögrencilerin son test puanlarından anlamlı derecede yüksek olduğunu tespit etmiştir.

Gelişim psikolojisi bağlamında mizah gelişimi kavramının Türkçe öğretiminde varlı̆̆ını ve geleneksel türlerin Türkçe ders kitapları içinde mizahi unsurlar anlamında ne kadar yer ettiğini ortaya koymaya çalışan bu araştırmada da yukarıdaki çalışmaların bulgu ve sonuçları ile örtüşen şu sonuçlara ulaşılmıştır: 
Mizah yapıları Türkçe ders kitabının iskeletini oluşturan ünitelerin tamamında değil; belli ünitelerde karşımıza çıkmaktadır. Bu dağılım sınıf düzeyinde de nicel olarak farklılaşmaktadır. Yazılı ve görsel yapıları bir arada kullanılmış, görsel mizah ögeleri karikatür şeklinde yoğunlaşmışken yazılı mizah unsurları ise farklı türler içerisinde yer almıştır. Kendini geliştirici ve katılımcı mizah tarzlarına dair olumlu mizah yapıları ders kitaplarında yer bulabilmiştir.

Araştırmanın diğer ve önemli bir boyutunu oluşturan Türk yazınının içerisinde mizah barındıran geleneksel türlerin ve mizahi tiplerin Türkçe öğretiminde ne kadar yer aldığı ve metinlere ne kadar yansıdığının incelenmesinden elde edilen sonuç ise genel hatlarıyla şu şekildedir: fikra, deyim, atasözü, öykü, Karagöz gibi türler kitaplarda yer almış ve bu türler içerisinde mizah unsurları yer bulmuştur. Bununla beraber orta oyunu, köy seyirlik oyunları, meddah, kukla gibi türler yer almamış; sadece bunlardan birkaçı tanımlama, kavramın açıklanması şeklinde yer bulmuştur. Mizah kavramını doğrudan ifade eden fikraya bu türler içerisinde en belirgin şekilde ders kitaplarında yer verilmiştir. Türk fikra tiplerinden Nasrettin Hoca ise bu fikra tiplerinin örneğini teşkil etmiştir.

\section{Öneriler}

1. Okullarda, özellikle Türkçe derslerinde öğrencilerin; yaratıc1, eleştirel ve özgür düşünebilecekleri öğrenme-öğretme ortamlarının oluşturulmasında, öğrencilerin genelde okula özelde Türkçe derslerine yönelik olumlu tutum geliştirmelerinin sağlanmasında ve ilgilerinin arttırılmasında mizahtan daha fazla yararlanılması önerilmektedir.

2. Türkçe ders kitaplarının yazılı mizah ögelerinin yanında, görsel mizah ögeleriyle de zengin hâle getirilmesi önerilmektedir.

3. Türkçe ders kitaplarında metin seçimi yapılırken mizah gelişimini de destekleyecek metinlerin seçilmesine özen gösterilmelidir.

4. Mizahi yapıları barındırmaları yönünden Türkçe ders kitaplarını meydana getiren üniteler dengeli oluşturmalıdır.

5. Öğrencilerin gelişimleri dikkate alınarak mizah, geleneksel türler de dâhil olmak üzere bütün türleriyle öğrenciler ile buluşturulmalıdır.

6. Ders kitaplarının yanı sıra, öğretmenler de öğrencilerin mizah gelişimini destekleyecek kuramsal bilgiye sahip hâle getirilmeli, bu bağlamda yetiştirilmelidirler. 


\section{Kaynaklar}

Akben, C. (2018). Mizah tarzlarının ve çeşitli kiş̧ilik özelliklerinin yaratıcılığa etkisi. Doktora Tezi, Bolu Abant İzzet Baysal Üniversitesi, Sosyal Bilimler Enstitüsü, Psikoloji Anabilim Dalı, Bolu.

Aydın, S. (2006). Türkçe derslerinde mizah kullanımının öğrenci tutum ve başarısına etkisi. Doktora Tezi, Dokuz Eylül Üniversitesi, Eğitim Bilimleri Enstitüsü, Türkçe Eğitimi Anabilim Dal, İzmir.

Aylor, B \& Oppliger, P. (2003). Out-of-Class Communication and Student Perceptions of Instructor Humor Orientation and Socio-Communicative Style.Communication Education, 52(2), 122-34.

Banas, J. A., Dunbar, N., Rodriguez, D. \& Liu, Shr-Jie (2011). A Review of Humor in Educational Settings: Four Decades of Research. Communication Education, 60 (1), $115-144$

Bergson, H. (2011). Gülme, İstanbul: Türkiye İş Bankası Kültür Yayınları.

Berlyne, D.E. (1972). Affective aspects of aesthetic communication. In T. Alloway, L. Krames, ve P. Pliner (Edt.), Communication and Affect: A Comparative Approach. New York: Academic.

Bolkan, S., Griffin, D. \& Goodboy, Al (2018). Humor in the classroom: the effects of integrated humor on student learning. Communication Education, 67(2).

Bowen, A. G. (2009). Document analysis as a qualitative research method. Qualitative Research Journal, 9(2), 27-40.

Corbin, J., \& Strauss, A. (2008). Basics of qualitative research: Techniques and procedures for developing grounded theory (3rd Ed.). Thousand Oaks, CA: Sage.

Creswell, J. W. (2007). Qualitative inquiry \& research design: Choosing among five approaches (2. Baskı). USA: SAGE Publications.

Erdal, K., Celepoğlu, A., Kılıç, Y., Arıcı, A. F. \& Kara, R. (2011). Çocuk edebiyatının kaynakları. Ö. Yılar ve L. Turan (ed.), Çocuk Edebiyatı (3.Basım) (ss.67-200) içinde. Ankara: Pegem Akademi.

Esendemir, N. \& Ertaş, N. (2018). Ortaokul Türkçe ders kitaplarindaki göç olgusuna dair unsurlar. Kuram ve Uygulamada Sosyal Bilimler Dergisi, 2 (2), 72-80

Haykır, H., Kaplan, H., Kıryar, A., Tarakçı, R. \& Üstün, E. (2018). Ortaokul ve İmam Hatip Ortaokulu 5. Sinıf Türkçe Ders Kitabı, Ankara: Devlet Kitapları, Özgün Matbaacılık.

Karasar, N. (2007). Bilimsel araștirma yöntemleri, Ankara: Nobel yayınları

Kaya, B. (2018). Ortaokul ve Imam Hatip Ortaokulu 7. Sinıf Türkçe Ders Kitabı, Ankara: Ders Destek Yayınları.

Kılınç, A. (2008). Öğretimde mizahi kavramaya dayalı bir materyal geliştirme çalışması: Bilim karikatürleri. Doktora Tezi, Gazi Üniversitesi, Eğitim Bilimleri Enstitüsü, Biyoloji Eğitimi Bilim Dalı, Ankara.

McGhee, P. E. (2002). How humor facilitates children's intellectual, social and emotional development. Child Development, 52, 925-931

Merriam, S. B. (1998). Qualitative Research and Case Study Applications in Education. San Francisco: Jossey-Bass Publishers

Merriam, S. B. (2013). Nitel araşttrma: Desen ve uygulama için bir rehber (3. Baskıdan Çeviri, Çeviri Editörü: S. Turan). Ankara: Nobel Yayın Dağıtım 
Mete, G., Karaaslan, M., Kaya, Y., Ozan, Ş. \& Özdemir, D. (2018). Ortaokul ve İmam Hatip Ortaokulu 8. Sinıf Türkçe Ders Kitabl, Ankara: Devlet Kitapları, Saray Matbaacılık.

Miles, M.B. \& Huberman, A.M. (1994). Qualitative Data Analysis: A Sourcebook of New Methods (2nd ed.). Thousand Oaks, CA: Sage.

Morreall, J. (1997). Gülmeyi Ciddiye Almak, (çev. Kubilay Aysevener - Şenay Soyer) İstanbul: İris Yay.

Oruç, Ş. (2006). Sosyal bilgiler öğretiminde mizah. Doktora Tezi, Gazi Üniversitesi Eğitim Bilimleri Enstitüsü Sosyal Bilgiler Öğretmenliği Anabilimdal, Ankara.

O'leary, Z. (2004). The Essential Guide to Doing Research. London: Sage Publications Ltd. s. 177

Özkan, U. B. (2019). Eğitim Bilimleri araştırmaları için döküman inceleme yöntemi. Ankara: Pegem

Şakiroğlu, Y. (2018). Mizah temelli etkinliklerin 7. sinı öğrencilerinin anlatma becerilerine etkisi. Doktora Tezi, Ağrı İbrahim Çeçen Üniversitesi, Sosyal Bilimler Enstitüsü, Türkçe Eğitimi Anabilim Dalı, Ağrı.

Schatz, M. \& LoSchiavo, F. (2006). Bringing Life to Online Instruction with Humor. Radical Pedagogy, http://www.radicalpedagogy.org/radicalpedagogy/Bringing_Life_to_Online_Instruction

Schmidt, S. (2002). The humour effect: Differential processing and privileged retrieval. Memory, 10, 127-38.

Subaşı, M. \& Okumuş, K. (2017) Bir araştırma yöntemi olarak durum çalışması. Atatürk Üniversitesi Sosyal Bilimler Enstitüsü Dergisi, 21(2): 419-426

Summerfelt, H., Lippman, L., \& Hyman, I. (2010). The effect of humor on memory: Constrained by the pun. The Journal of General Psychology, 137, 376-394.

Şahin, A. (2018). Yönetsel ve Eğitsel Araç Olarak Eğitim Kurumlarında Mizah, Ankara: Anı Yayıncilik.

Şekerci, Y. (2018). Ortaokul ve İmam Hatip Ortaokulu 6. Sinıf Türkçe Ders Kitabı, İstanbul: Eksen Yayincilik.

Tavşancıl, E. \& Aslan, E. (2001). İçerik analizi ve uygulama örnekleri. Epsilon Yayınları, TDK Büyük Türkçe Sözlük (2011). Ankara TDK Yayınları.

Topçuoğlu, H. (2007). Eğitimde mizahın önemi. Bilim ve Aklın Aydınlığında Eğitim Dergisi, $84,38-43$.

Usta, Ç. (2009). Mizah dilinin gizemi, Ankara: Akçağ Yayınları.

Yanık, H. B.. Özdemir, G., \& Eryılmaz Çevirgen, A. (2017). Investigating data processing related tasks in middle school mathematics textbooks, Inоnи University Journal of the Faculty of Education, 18(2), 45-61. DOI: 10.17679/inuefd.323407

Yıldırım, A. \& Şimşek, H. (2013). Sosyal bilimlerde nitel araştırma yöntemleri. Ankara: Seçkin.

Yin, R. (1984). Case Study Research: Design and Methods. (3. Basim). California: Sage Publications.

Vance, C. (1987). A comparative study on the use of humor in the design of instruction. Instructional Science, 16(1), 79-100. 
Wanzer, M.B., Frymier, A.B., \& Irwin, J. (2010). An explanation of the relationship between instruction humor and student learning: Instructional humor processing theory. Communication Education, 59(1), 1-18.

Ziv, A. (1983). The influence of humorous atmosphere on divergent thinking. School Psychology International 1(2), 21-23.

Ziv, A. (1988). Teaching and learning with humor: Experiment and replication. The Journal of Experimental Education, 57 (1) 1, 5-15.

Zorluoğlu, S. Z., Kızılaslan, A. \& Sözbilir, M. (2016). Ortaöğretim kimya dersi öğretim programı kazanımlarının yapılandııılmış Bloom taksonomisine göre analizi ve değerlendirilmesi. Necatibey Eğitim Fakültesi Elektronik Fen ve Matematik Eğitimi Dergisi (EFMED), 10 (1), 260-279. 
